\title{
An analysis of the relationship between faculty perception of administrative support and the faculty perceived levels of implementation of good teaching practice in distance education
}

\author{
Carol L. Fugitt \\ West Virginia University
}

Follow this and additional works at: https://researchrepository.wvu.edu/etd

\section{Recommended Citation}

Fugitt, Carol L., "An analysis of the relationship between faculty perception of administrative support and the faculty perceived levels of implementation of good teaching practice in distance education" (2006). Graduate Theses, Dissertations, and Problem Reports. 3466.

https://researchrepository.wvu.edu/etd/3466

This Dissertation is protected by copyright and/or related rights. It has been brought to you by the The Research Repository @ WVU with permission from the rights-holder(s). You are free to use this Dissertation in any way that is permitted by the copyright and related rights legislation that applies to your use. For other uses you must obtain permission from the rights-holder(s) directly, unless additional rights are indicated by a Creative Commons license in the record and/ or on the work itself. This Dissertation has been accepted for inclusion in WVU Graduate Theses, Dissertations, and Problem Reports collection by an authorized administrator of The Research Repository @ WVU.

For more information, please contact researchrepository@mail.wvu.edu. 
An Analysis of the Relationship between Faculty Perception of Administrative Support and the Faculty Perceived Levels of Implementation of Good Teaching Practice in Distance Education

\section{Carol L. Fugitt, EdD}
Dissertation submitted to the Faculty of the College of Human Resources and Education at West Virginia University
in partial fulfillment of the requirements for the degree of
Doctor of Education
in
Higher Education/Leadership Studies

Committee Chair, Mike Cunningham

Teresa R. Eagle, EdD

Ernest Goeres, EdD

Robert Rubenstein, EdD

Voilette Eash, PhD

Morgantown, West Virginia, 2006

Keywords: Distance Education, best practices, faculty support, student support, technology

Copyright 2006 by Carol L. Fugitt 


\title{
ABSTRACT \\ An Analysis of the Relationship between Faculty Perception of Administrative Support and the Faculty Perceived Levels of Implementation of Good Teaching Practice in Distance Education
}

\author{
by Carol L. Fugitt
}

The faculty perceptions of administrative support for distance education and best distance education teaching practice were investigated. Participants were selected from the 2004-2005 full-time distance education faculty at Kentucky Community and Technical College, $n=432$. The researcher developed a self-report survey, the Good Practices Survey, as a means to collect data for the research. Research questions investigating the relationship between four independent variables and perception of good distance education teaching practices were significant indicating that faculty perceive administrative support when implementing good distance education teaching practice. Research questions investigating the relationship between faculty support, student support, and support for assessment were significant. However, research questions investigating the relationship between administrative support for technology and good distance education teaching practice indicated no significance. Further research is needed more information is needed to (a) identify motivational factors of the distance education faculty member; (b) further investigate the various concerns addressed by administration and faculty of distance education, and (c) elaborate on how leadership responsibilities at each level of support or hinder the delivery of quality distance education programs. 


\section{DEDICATION}

This dissertation is dedicated to my mother, Anna W. Fugitt who, if given the chance, would have been the greatest college student ever! Thank you mom and dad for taking care of the most precious person in my life, my son Joshua so that I could accomplish this goal. I love you all. 


\section{ACKNOWLEDGMENTS}

To those individuals who played the supporting role in this drama-

Dr. Michael Cunningham, for agreeing to chair my committee and see me through this experience.

Dr. Teresa Eagle, for always knowing the right thing to say when I needed a good dose of encouragement.

Dr. Robert Rubenstein, for helping put this task into perspective and for reminding me that life is too short to get uptight.

Dr. Ernest Geores, for having such a good sense of humor through all of this. Anyone who uses the phrase, "tighter than ballerina britches" is okay in my book.

Dr. Violet Eash, who inspired me to keep going after graduate school.

Dr. Michael Galbraith, who picked me up, brushed me off, and put me back on the horse.

Dr. Dennis Prisk, who loved to pick on me in class, which made me study harder so I wouldn't embarrass myself too much.

Deb Woods, who always made me laugh which kept everything in perspective. You are the worker bee!

Char Allen, thank you for paying attention to detail and all of the last minute favors to make things happen. You went the extra mile for the student!

To my friends who kept me going-

Thank you Karen Kirtley, Barbara “Baabs” McDermott, Norma Hodge-Thompson, and Craig Hardesty for the venting sessions during the long drives to and from class. You guys are the best! 


\section{TABLE OF CONTENTS}

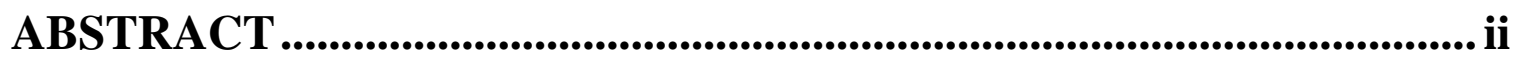

ACKNOWLEDGMENTS .................................................................. iv

TABLE OF CONTENTS .................................................................................... v

LIST OF TABLES .................................................................................. vi

CHAPTER I....................................................................................................... 1

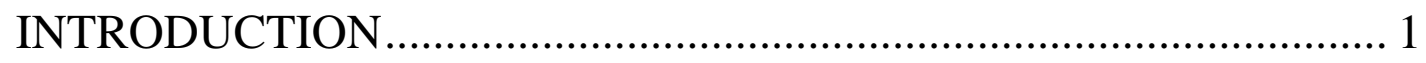

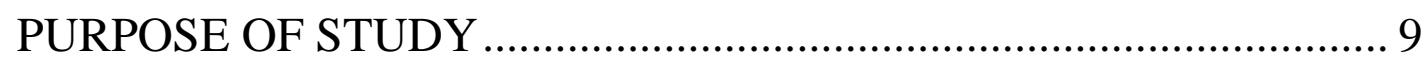

RESEARCH QUESTIONS ................................................................ 10

OPERATIONAL DEFINITIONS ........................................................ 11

SIGNIFICANCE OF STUDY …………………………………...... 12

LIMITATIONS OF STUDY............................................................ 14

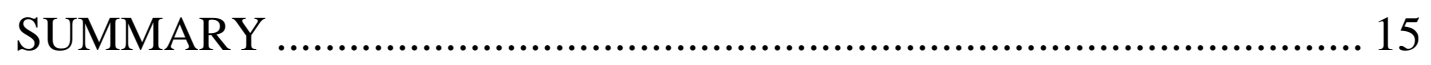

CHAPTER II ........................................................................................ 17

REVIEW OF LITERATURE ……………………………………... 17

HISTORY OF DISTANCE EDUCATION ........................................... 18

ADMINISTRATIVE SUPPORT OF GOOD DISTANCE .................... 24

EDUCATION TEACHING PRACTICE ………………………………... 25

Administrative Support for Faculty ……………………………….... 27

Administrative Support for Students....................................................... 31 
Administrative Support for Providing Appropriate Technology ........ 34

Administrative Support for Providing Appropriate Assessment ........ 38

GOOD TEACHING PRACTICE BY DISTANCE EDUCATION

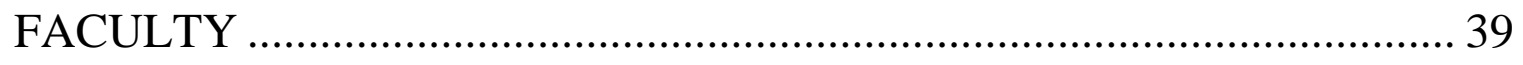

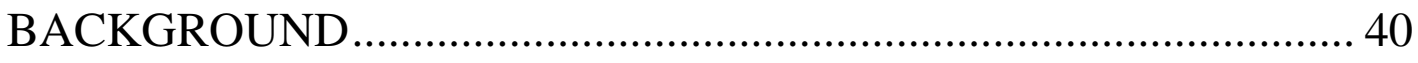

Implementation for Appropriate Technology ................................... 42

Student Support by Faculty .......................................................... 43

Faculty Implementation of Technology .......................................... 47

Assessment of Course Quality by Faculty ......................................... 49

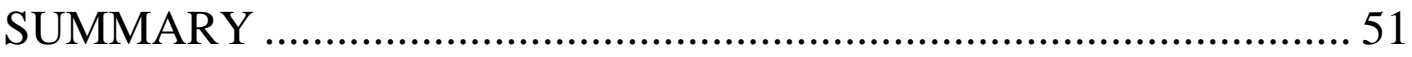

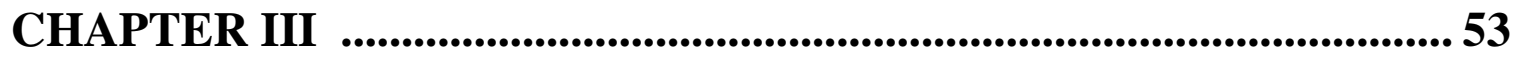

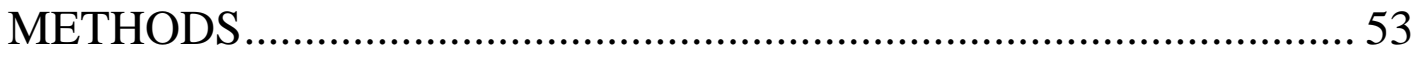

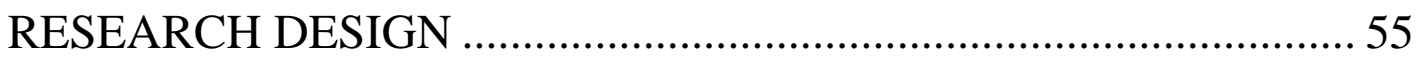

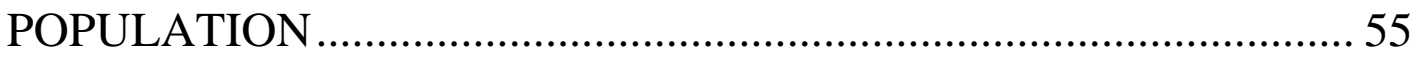

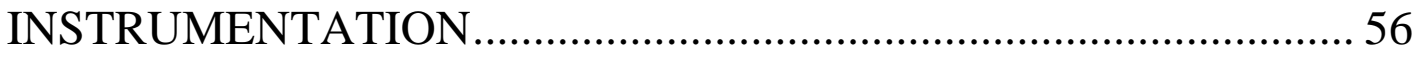

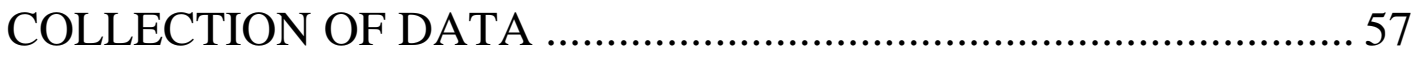

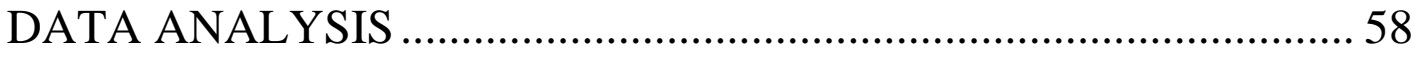

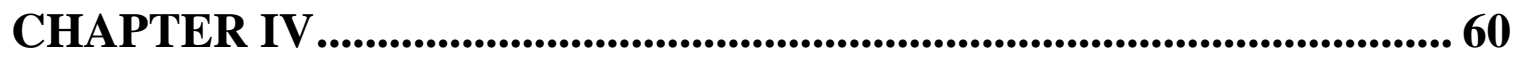

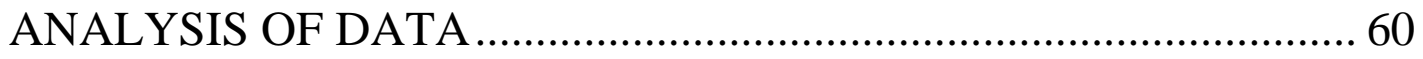

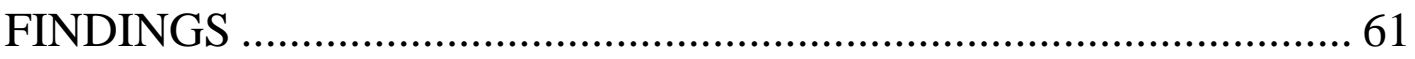


SUMMARY

64

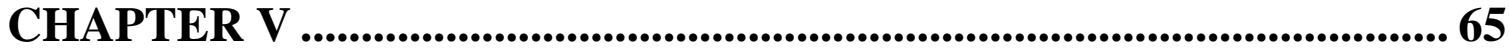

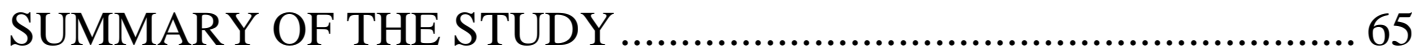

FINDINGS AND CONCLUSIONS ................................................66

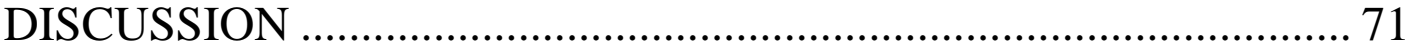

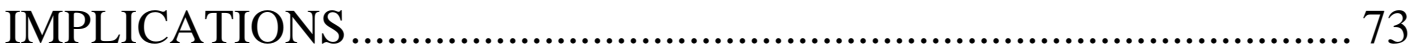

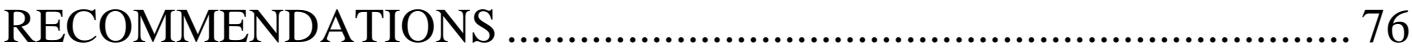




\section{LIST OF TABLES}

Correlations Between Administrative Support and Faculty

Implementation of Good Distance Education Teaching Practice........ 64 


\section{Chapter I}

\section{Introduction}

Distance education has found a permanent niche among the instructional alternatives available at many universities around the world (Saba, 2005). It is "the process whereby the education of students occurs in circumstances where the educator and the student are geographically separated, and the communication across this distance is accomplished by one or more forms of technology" (American Association of University Professors, 1998, p. 32). In the past, distance education only consisted of correspondence courses that the majority of learners found unacceptable. However, with the advancement of technology, distance education has become more attractive for students (Dahl, 2005; Russell, 1999).

Distance education was initiated as a way for rural universities to increase student enrollment and offer educational opportunities to remote areas of the state. Therefore, educational administrators of distance education throughout the United States have shown an increased interest in the development and delivery of distant education. For example, in the western part of the United States, the Hispanic student population has grown due to the expanded number of distance education programs (Burnett, 2001). In the northern part of the United States, distance education was implemented to expand and enhance the academic offerings to reach a new student population. In the southern states, the increase of student enrollment 
in single courses has improved educational programs to help rural students with access to adult and continuing education classes, workforce development and higher education placement (Bash, 2005).

In the 2002-03 school year, approximately two-thirds of colleges and universities offered distance education (Sachs, 2004). Rural schools have the highest percentage of distance learning opportunities while urban schools have the least (Sachs, 2004). As the number of programs and students enrolled in distance education continues to increase, the responsibility of administration and faculty to implement good practices continues to expand.

In the academic year 1994-95, only 5\% of the 15 million United States college students enrolled in distance education programs (International Data Corporation, 1999). During the academic year 1997-98, approximately 1.6 million students enrolled in distance learning courses throughout the United States (United States Department of Education, 1999). To support this increase in enrollment, more than half of the nations two and four-year degree granting institutions offered distance education courses in the 2000-2001 academic year (National Center for Education Statistics, 2003).

Distance education is popular because it is more flexible for students, instructors, and institutions than is traditional instructional course delivery (Calvert, 2005; Morris, 1999; Moore \& Thompson, 1997). Supporters of distance 
education claim that distance education is more convenient and accessible for nontraditional students. Critics of distance education, however, question whether the expense of providing such courses is cost efficient (Barab \& Duffy, 2000). Regardless of these conflicting beliefs, the continued rapid growth of distance education poses major strategic challenges for higher education (Eaton, 2002).

One major challenge for institutions, as well as accrediting agencies, is to protect the quality of education. There is a small set of core academic values including shared governance and academic authority of faculty, which is central to the history, and tradition of higher education (Barab \& Duffy, 2000). Distance education challenges administration to maintain these values.

To address this challenge, the Western Interstate Commission for Higher Education (WICHE) developed the Principles of Good Practice for Electronically Delivered Academic Degree and Certificate Programs. The Principles emphasize incorporation of distance learning into an institution's overall mission, and emphasize commitment of support to finances, technical resources, and faculty (Johnstone, 1996). Also included are best practices for administration to most effectively support faculty pedagogy, student services, technology, and assessment policies.

The major areas of administrative support for distance education addressed in the Principles include: 
1. Faculty support should include incentives for faculty involvement, adequate training and support specifically related to teaching via an electronic system.

2. The student support component indicates that distance education students should have access to all of the same student services as their on-campus counterparts.

3. The administration assures adequacy of technical and physical plant activities including appropriate staffing and technical assistance, to support distance education courses and students.

4. The administration collects empirical data from faculty and students to determine the facets of distance education. These are used to develop a holistic distance education assessment instrument that takes the uniqueness of varying delivery methods into account (pp. 34-37).

Most accrediting agencies have standards or policies in place for evaluating distance education. There is variation among the agencies as to the degree to which they require institutions to assess their distance education program (Huszmann \& Miller, 2001). However, by extension, the Principles also provide faculty insight into the level of administrative support needed to implement a successful distance education course (DeCastro, 1999). 
The perceptions of faculty with regard to institutional support, and whether their perception of administrative support has a relationship to faculty implementation of appropriate pedagogy, have not been adequately investigated (Young, 2000). Guide (2005) noted that college and university administrative support induces strong faculty motivation to participate in distance education programs. McKenzie (2000) suggested that faculty motivation to implement best practice strategies to overcome challenges of best teaching practice in distance education is a key factor to the success of distance education.

These strategies of appropriate pedagogy of faculty addressed in the Principles involve:

1. Faculty level of implementation of appropriate pedagogy;

2. Faculty level of student support through interaction and communication;

3. Appropriate use of technology for student support;

4. Assessment of course quality.

Guide (2005) suggests there are several identifying factors to quality distance education pedagogy. First, faculty should identify the learning goals and objectives which will support a foundation for the instructional design, development, and delivery of a distance education course (Guide, 
2005). Second, instructional activities should be directed toward providing learners with the knowledge and experience required to meet the goals and objectives of the course (Guide, 2005). Third, instructional design and support should be based on the range of support services available to faculty and students (Guide, 2005). Finally, specific instructional activities should include technology to build collaborative learning environment where structure and dialogue are optimized (Guide, 2005).

Zhang (1998) suggested that student interaction with faculty play a substantial role in student support and "produces more substantial direct effects on student outcomes than almost any other environmental variable” (p. 56). This variable is affected by a number of factors, including faculty interest in students' problems, personal and academic, faculty sensitivity to issues of isolation, faculty accessibility outside the office hours, and the existence of outside opportunities to interaction (Levine, 1999). In a contrasting viewpoint, Mioduser (2003) reported that on-campus interaction is an important part of the impact of college. The influences of these oncampus interactions greatly affect student attitudes, values, and goals (Johnson, 1997).

The use of technology to advance distance education has become more important in the area of best practice strategies (Wilson, 2002). Dahl 
(2004) stated that regardless of the technology used by faculty, distance education courses compare favorably with classroom-based instruction with high student satisfaction. However, in a recent study by Roach (2002), the appropriate use and availability of technology is found to be instrumental in the success of a distance education program. Gallaher and Johnstone (2002) as well as Young (2000) suggested that interaction between students and faculty such as on-line discussion and tutorials, email and prompt feedback, is affected by the use of technology.

Other issues of concern pertain to academic quality, effectiveness and content of course material in distance education (Campbell, 2000). In the past, research has focused primarily on student attitudes and overall student satisfaction to assess an effective distance education program (Burnett, 2001). Today, assessment by faculty plays an important role in legitimizing the distance education process to ensure that each course is consistent with the academic program’s curriculum (Russell, 1999).

Identifying and understanding the appropriate element for assessment when compared to traditional learning is more complex in distance education (Smith, 2005). When compared to traditional learning, there are more elements to consider in the assessment process. Therefore, it is much harder for faculty to find criteria by which to assess their course design. Due 
to this disadvantage, some institutions have been referred to as "diploma mills,” instilling a negative academic reputation (Easterday, 1997; Clow, 1999). On the other hand, supporters claim that distance education is an economical tool for offering academic courses to geographically isolated students (Burnett, 2001). The use of distance education in this situation has made access to higher education a reality for persons in rural states such as Kentucky (Young, 2000). Despite the many difficult issues facing rural communities, much is being done to enhance the opportunities of this population. Community colleges, by taking a lead role in community development, help serve the need of their constituencies and improve the standard of living (Campbell, 2001).

\section{Statement of the Problem}

Distance education is comprised of many different components. As colleges and universities move forward in the development and implementation of distance education programs, it is imperative to understand the necessary components of distance education. These components are centered on the support administration give their faculty as well as the amount of support faculty give their students. The research directed towards student perceptions of course work, quality of distance education, and administrative support of programs is rather extensive. However, 
there is paucity information concerning faculty perceptions as they relate to the good practices of distance education (Ganzel, 1999). Associated with the omission of faculty inclusion as related to design and delivery of distance education, are issues of faculty's perception of administrative support and implementation of good teaching practices. This lack of essential information has created a less than holistic approach to the distance education model.

\section{Purpose of the Study}

The purpose of this study was to analyze the relationship between faculty perceptions of administrative support for distance education and the levels of implementation of appropriate pedagogy as perceived by the faculty of rural community colleges. The Kentucky Community and Technology College System (KCTCS) is an example of a rural community college (Young, 2005). KCTCS, formally known as University of Kentucky Community College System, provides a career-oriented technical program, pre-baccalaureate education and adult continuing education programs.

The KCTCS includes community colleges in Henderson, Maysville, Hazard, Madisonville, Ashland, Somerset, Owensboro, Prestonsburg, Southeast, Paducah, Hopkinsville, Jefferson, and Elizabethtown. Thousands of students are currently enrolled in the KCTCS distance education programs and the number is growing (McCall, 2003). During the 1998 academic year, KCTCS reported an enrollment 
of 83 distance education students (McCall, 2003). Enrollment in distance learning courses rose to 9,821 students in Fall, 2002. Fully online course use has increased 749\% since 1999 (McCall, 2003). In a survey jointly administered by Babson College and Sloan-C, the expected growth rate for distance education students are 24.8\% in 2004; up from 19.8\% in 2003 (Bash, 2005). With this boom in enrollment and responsibility, administrators as well as faculty began to look for best practice models to provide guidelines for planning and assurance of accountability (Schifter, 2000). KCTCS leadership is especially interested in the faculty perceptions of institutional support (McCall, 2003). Therefore, the following research questions were addressed.

\section{Research Questions}

Q1. What is the relationship between the faculty perceived level of administrative support for faculty and faculty implementation of good distance education teaching practices?

Q2. What is the relationship between faculty perceived level of administrative support for students involved in distance education and faculty implementation of good distance education teaching practices?

Q3. What is the relationship between the faculty perceived level of administrative support for technology and faculty implementation of good distance education teaching practices? 
Q4. What is the relationship between the faculty perceived level of appropriate distance education assessment policies and the implementation of appropriate distance education?

The following operational definitions were chosen to further define and clarify the study.

\section{Operational Definitions}

1. Implementation of Good Teaching Practices - the respondent's score on the level of implementation of the good teaching practice components of the Good Practices Survey.

2. Faculty Perception of the Level of Administrative Support for Distance Education Faculty - the respondent's score on the level of implementation component of the Good Practices Survey.

3. Faculty Perception of the Level of Administrative Support for Distance Education Students - the respondent's score on the level of implementation component of the Good Practices Survey.

4. Faculty Perception of the Level of Administrative Support for Distance Education Technical services - the respondent's score on the level of implementation component of the Good Practices Survey. 
4. Faculty Perception of the Level of Administrative Support for Distance Education Assessment Procedures - as defined by the respondent's score on the level of implementation component of the Good Practices Survey.

\section{Significance of Study}

The findings of this study contribute to sound academic practices in distance education especially as it relates to community colleges. An organizational setting where faculty incentives are attainable and administrative support is at high levels should play a significant role in students receiving a higher quality of education. Therefore, identifying faculty perceptions regarding administrative support and the impact of these perceptions on the implementation of appropriate pedagogy is important.

The results of this study also provide community college administrators with information concerning best practices within a community and technological college distance education program as perceived by the faculty. By identifying faculty perceptions from existing distance learning programs, community college administers wishing to initiate or enhance distance-learning programs could utilize any of the characteristics identified in this research endeavor. This study will be 
important to the community college system interested in expanding existing programs. It will also be important for those administrators who want to begin distance learning programs and who may demonstrate hesitance and concern for what could be an expensive and difficult endeavor. In addition, more community colleges could utilize these successful models in their own states.

Rapid changes in technology have created new opportunities for distance education in community colleges. With these opportunities come new challenges for maintaining quality. One way to maintain quality is to implement the good practices for distance education programs identified in the literature. This study provides insight into the perceptions of Kentucky Community and Technology faculty on the extent to which good practices for distance education are being implemented in their distance education programs as well as the level of institutional support for distance education programs. The results of this study contribute to the body of knowledge pertaining to the best practices of distance education. However, the results of this study are subject to certain limitations as outlined below. 


\section{Limitations}

1. The credibility of the results is limited to the extent that respondents answered the survey questions honestly. The use of an anonymous survey will help protect respondents and promote objective reporting. Respondents will be assured of anonymity and confidentiality. Individual responses will not be made public.

2. Surveys were returned voluntarily. The completion and the return of the survey may be influenced by the satisfaction of the respondent with distance education or by the convenience or inconvenience of completing the survey.

3. Difficulties with validity, reliability and generalizing are often related to any survey instrument. All care was taken to ensure that these difficulties are addressed in the instrumentation design and in the pilot study.

4. The sample was limited to faculty within the KCTCS who are currently employed at KTCTS.

5. The results were limited to those surveys returned during the timeline of the study.

6. The results of this study did not intended to be generalized to 
the populations other than the population sample.

7. This study will not address faculty personality or emotional states, which may affect their perceptions concerning the level of administrative support for distance education programs.

\section{Summary}

This chapter introduces the issue of distance education and best practices. It is suggested that faculty inclusion and perceptions are an omission in the research they relates to design, development, and delivery of distance education. This study sought to analyze faculty perceptions of administrative support for faculty, student services, technology, and assessment policies. The purpose of this study was to analyze the relationship, if any, between faculty perceptions of administrative support for distance education and the levels of appropriate of good distance education pedagogy as perceived by the faculty of a rural community college. Four research questions are presented as well as a section on operational definitions. The chapter ends with a discussion of the significance of the study and the limitations that are present. To better understand the issue of distance education and the implementation of best practices, the next chapter will focus on the current literature. Chapter three will describe the methods for implementing the study and chapter four will present the findings of this study. The final chapter will focus on 
the summary, conclusions, implications, and recommendations that can be drawn from the findings. 


\section{Chapter II}

\section{Review of Literature}

The purpose of this study was to analyze the relationship between faculty perceptions of administrative support and the levels of implementation of good teaching practices as perceived by the faculty of rural community colleges. A number of variables make such an analysis critical. The Kentucky Community College System, which originated in 1962, provides career-oriented technical programs, prebaccalaureate education and adult-continuing education programs. In 1997, Governor Paul Patton proposed, and the General Assembly approved the Kentucky Postsecondary Education Improvement Act of 1997. This Act allowed the state’s 15 postsecondary technical schools to leave state government to became technical colleges and join the Kentucky Community and Technical College System. After completing an accreditation process in 1998, Kentucky's newest postsecondary education system was in place when the Kentucky Community and Technical College System assumed management of thirteen of Kentucky's 14 community colleges. The KCTCS includes 13 community colleges in Henderson, Maysville, Hazard, Madisonville, Ashland, Somerset, Owensboro, Prestonsburg, Southeast, Paducah, Hopkinsville, Jefferson and Elizabethtown. 
Thousands of students are enrolled in the Kentucky Community and Technological College System and the number is growing statewide (Young, 2005). In September 2002, official enrollment was reported to be 67,813 full and part time students in credit programs (Young, 2005). This figure represents a 7.4\% increase over fall 2001 enrollment of 63,120, and a 49\% increase over students enrolled in fall 1998, the first semester that two-year community colleges and technical colleges were joined in KCTCS (Young, 2005). Students enrolled in distance education courses also increased $62 \%$ (Young, 2005).

As enrollment is rapidly increasing, information is needed to best guide the implementation of practices for distance education. The literature suggests that there are specific good practices to implement in order to support quality programs. The concern of implementation of appropriate pedagogy will be explored in terms of the variables of faculty support, student support, technology, and assessment of course effectiveness.

\section{History of Distance Education}

Distance education is a process that creates and provides access to learning when time and distance separate the source of information and the learners (Freedman, 1999; Spooner \& Melba, 1998). Learning at a distance, 
alternatively referred to as correspondence study, home study, independent study, external study, distance education, and distance learning, is a method of delivering instructional courses. During the $19^{\text {th }}$ century, correspondence study was initiated to enable learners to receive instruction when they could not attend traditional classes (Mioduser, 2000). However, with the advancement of simultaneous audio and video, distance education has become more attractive for students (Russell, 1999).

Electronic information systems were a phenomenon of the second half of the $20^{\text {th }}$ century. The use of electronic information systems and technology changed the world at a rate never before experienced in history (Berenfield, 1996). The effects of this growing popularity were immediate and evident within educational institutions (Watson, 1990).

Other types of distance learning opportunities such as independent or home studies also have grown in popularity. Students enrolled in these types of study complete course work off campus with ongoing supervision from an instructor. Distance learning provides several types of educational opportunities, which involve emerging technologies and comparable overall definitions (Mioduser, 2000).

As technology-assisted distance education has become increasingly popular in recent years, traditional technologies such as mail, telephones, 
and fax, have played a major role in the success of distance education (Eddy, Burnett, Spaulding, \& Murphy, 1997).

Distance education has found a permanent niche among the instructional alternatives available at many universities around the world (Russell, 1999). Distance learning is popular because it is more flexible for students, instructors, and institutions than is traditional instructional course delivery (Moore \& Thompson, 1997; Morris, 1999). In general, success is attributed to access to the best instructors and educational resources (Spooner 1999).

In the past 30 years, a number of specialized distance teaching universities were established, including the Open University in the United Kingdom, the National Distance Education University in Spain, and the Open University in the Netherlands (Morris, 1999). Over the same time span, hundreds of more traditional universities across the world also expanded their distance education provision (Campbell, 2000). Although Universities have been involved in distance learning for decades, technology-based distance education is emerging as an increasingly important component of higher education (Arbough, 2000).

In 1999, Jones University became the first online-only university to gain accreditation by the Commission on Institutions of Higher Education of 
the North Central Association of Colleges and Schools (NCA) and enrolled 600 adult students (Morris, 1999). The for-profit University of Phoenix has already met the demand for distance education programs by educating more than 8,000 students on subjects ranging from nursing to computer science (Campbell, 2000; Morris, 1999). The variety of subjects was characteristic of the company that built the country's largest private university. The University of Phoenix offers students the flexibility of continuous enrollment and satellite campuses near freeway exits (Morris, 1999). Distance education is not new in the United States, but its reach remains limited. In the academic year 1994-95, only 5\% of the 15 million college students were enrolled in distance and correspondence programs (International Data Corporation, 1999). A reported one million students will take distance courses, most of which are on-line (International Data Corporation, 1999). There is evidence that distance programs are expanding. A study of colleges and universities provided evidence that only a third of the institutions offered distance programs in 1995 (International Data Corporation, 1999). In 1995 it was reported by the Department of Education that 58\% of two-year college's offer distance education courses. In 2002, the Department of Education reported over two million students enrolled in college-level distance education courses. Enrollments in distance education 
courses rose nearly $20 \%$ in 2003 with administrators predicting another $24 \%$ growth in enrollment in 2004 (Simonson, 2005).

\section{Community Colleges}

Initiated as an inexpensive way for rural universities to increase course offerings and enrollment distance education rapidly changed with the potential to elect distance education in community colleges. Because community colleges serve a diverse population that is often geographically isolated, they have been at the forefront of distance learning technology (Easterday, 1997). Online learning became an asset to people who could not afford to travel or who did not have the time to attend regular scheduled classes (Eddy, George, Spaulding, \& Murphy, 1997). At the same time, some instructors (Roach, 2002), colleges and universities as a whole (Smith, 2005) were slow to take advantage of new educational technologies. One of the primary reasons for their hesitation may be a negative attitude regarding the new educational tools (Bailey \& Chambers, 1996).

Burnett (2001) indicated that community colleges lead the way in implementing support for distance education. Both extension and distance education depend on learning resource centers to provide faculty and student services such as books, indexes, periodicals, audiovisual materials, and software (Young, 2000). Most accrediting commissions now expect 
colleges to provide comparable support services to students at off-campus locations in distance education (Ball, Jennie, \& Crook, 1997).

New technologies offer community colleges an opportunity to reform their educational delivery systems (Calvert, 2005). The explosion of technology and communications infrastructures allows community colleges to move beyond the geographic boundaries of their traditional target population (Calvert, 2005). Distance learning radically changes accessibility to higher education and alters conceptualizations of quality educational experience (Hassenplug \& Harnish, 1998). While criticisms of distance education often focus on the quality of the experience, the efforts to revise the policies, design and implementation of this new educational medium address these concerns (Burnett, 2001).

Educational administrators find distance education attractive as well, due to the potential cost advantages and its accessibility to a larger number of people in rural areas and in the workforce (Ganzel, 1999). Distance learning offers an opportunity for financially strapped community colleges to enhance their faculty resources by doing more with fewer people (Arbough, 2000). Presently, distance education through multimedia technology and the Internet is the newest solution for delivering instruction 
to learners who are unable to travel to campus or who simply prefer the convenience of online courses (Dede, 1996).

\section{Administrative Support of Good Practices for Distance Education Delivered Programs}

Institutional support in higher education refers to the kind of support the institution provides distance education programs to develop and improve instruction of on-line courses (Bash, 2005). Institutional support for faculty involved in distance education is essential and should take a variety of forms to recognize the range of motivations and needs of faculty as well as distant learners (Bash, 2005). This type of informative support typically comes from specialists such as instructional designers, editors, technicians, graphic designers, and librarians (Gaide, 2005). In a distance education environment, instructional support can take the forms of course redesign support, training in the use and application of distance education technologies, technical support, as well as student services and assessment guidelines (Sachs, 2004). According to (Gaide, 2005), instructional support is one of the key elements leading to successful distance education.

Accrediting agencies now expect colleges to provide comparable support services for faculty and students of distance education. These 
models of best practice involve components such as (a) providing leadership and commitment to faculty support, which involves granting release time to those responsible for developing and coordinating the services, securing the resources necessary for implementation, and training faculty to utilize the technology needed to deliver a successful distance course; (b) providing students with the on-line mentoring and tutoring, and library services; (c) providing appropriate technology for faculty to distribute course materials, and technological support for both faculty and student; and (d) providing ongoing assessment incorporating incoming data from faculty and students (Arbough, 2000).

The Council for Higher Education Accreditation (1998) reported that strategic plans for quality assurance in post-secondary education distance learning programs resembled those in traditional institutions and programs. This is due to the fact that a majority of distant learning providers in higher education are accredited institutions whose online courses are only an extension of on-campus courses.

While not an accrediting agency, the Western Interstate Commission for Higher Education (WICHE) developed the Principles of Good Practice for Electronically Delivered Academic Degree and Certificate Programs. The Principles emphasize incorporation of distance learning into an 
institution's overall mission, and emphasize commitment of support to finances, technical resources, and faculty (Johnstone, 1996). Included are sections on outcomes, coherency, completion, alternative delivery time, interaction, and faculty oversight.

The major areas of best administrative support practices addressed in the Principles include:

1. Faculty support should include incentives for faculty involvement, adequate training and support specifically related tot teaching via an electronic system.

2. The student support component indicates that distance education students should have access to all of the same student's services as their on-campus counterparts.

3. The institution assures adequacy of technical and physical plant activities including appropriate staffing and technical assistance, to support distance education courses.

4. Empirical data should be collected from faculty and students to determine the facets of distance education. This data should be utilized to develop a holistic distance education assessment instrument that takes the uniqueness of varying delivery methods into account. 
It is important to note that although the Principles specifically addresses electronically offered academic degree and certificate programs, not all distance learning programs use technology to deliver instruction, and not all colleges offer complete degree and/or certificate programs via distance education. However, by extension, the Principles can provide insight into good practices in distance education (Bash, 2005).

\section{Administrative Support for Faculty}

Distance education has provided community colleges with the potential to offer new learning opportunities unrestricted by time, distance, or individual differences among students (Campbell, 2000). However, traditional educational practices cannot accommodate distance education without corresponding shifts in the fundamental views of pedagogy (Easterday, 1997). Faculty bring a range of expectations and backgrounds with them in any type of professional development activity. Usually these expectations are set by the patterns of traditional classroom pedagogy such as an active, present instructor, instructor-directed activities and discussions, and a passive or merely responsive role for students (Dewald et al., 2000). Web-based pedagogy, by contrast, tends to reverse these dynamics, making the instructor less present and increasing the interactive and leadership roles of the learners (Hodgson, 1999). 
With the movement towards greater use of instructional technology by faculty, more educational administrators are asking faculty to teach distance education courses to accommodate student needs (Padgett \& ConceaoRunlee 2000). Institutional support in distance education refers to the kind of support the institution provides faculty members to develop and improve their instruction of on-line courses. An example of institutional support for faculty involvement is to offer rewards that promote these endeavors. A recent national survey conducted by the National Education Association (NEA) reported $63 \%$ of distance learning faculty is monetarily compensated for a distance learning course as if it were a normal course (NEA, 2000). A study by Johnstone (2002) concluded that overall faculty believes it is very important to obtain further education about, assistance with, or support from the institution for (a) developing interaction, (b) developing instructional materials, and (c) applying selected technologies.

The importance of faculty support and training to the success of any distance education or instructional technology effort has been widely acknowledged in education literature (Beaudoin, 1990; Dillon \& Walsh, 1992; Kalke, Macy, \& Rooney, 1998; Siegel, Jennings, Conklin). Although the literature on distance education has focused primarily on 
program design, assessment, and logistics, concerns are being expressed about the quality and appropriateness of teaching at a distance.

According to a number of higher education officials and experts, many institutions typically introduce training opportunities for faculty long before considering implementing a technology requirement (Dewald, Scholz-Crane, Booth, \& Levine, 2000). To ensure the best educational product is delivered to all students, institutions and faculty members must engage in careful planning and preparation (Berenfeld, 1996). Faculty who opt to teach distance education must be trained to integrate and enhance traditional course materials by creating richer, more interactive materials (Broderick \& Caverly, 1997). In a 2002 study by Rockwell, Schauer, Fritz, and Marx, the institutional support given to faculty to develop instructional materials that blend technology and utilize mediated information and instruction was reported as being very important to the success of distance education courses. Some institutions require faculty to attend training courses to learn different teaching styles and pedagogies.

Although faculty may be lured by the freshness that distance education provides, the type of instructional delivery depends on the faculty's knowledge of distance education courses and experience (Hodgson, 1999). Because teaching distance-learning classes involves new roles for 
instructors, administrators must provide them with the time, the tools, and the training to meet these new responsibilities (Young, 1997). Another incentive used by institutions to encourage faculty to get involved in institutional initiative is workload adjustment. Bower (2001) argued that if institutions provide release time to faculty preparing distance learning courses, they may need to demonstrate increased productivity through other means such as increased student/faculty ratio in distance learning classes.

In order for distance education to be effective in professional development, administration must consider the gap between the typical teacher's expectation about the learning process and the capabilities and characteristics of instruction over distance (Newby, Stepich, Lehman, \& Russell, 2000). Experts indicate that the administration's preparation of faculty members to teach distance learning courses is necessary and must be multi-faceted (Padgett \& Concceao-Runlee, 2000). Educational opportunities for faculty need to focus on providing student-learning experiences that support an interactive learning environment. Distance learning programs should educate faculty on how to fulfill these new interactive roles (Newby, Stepich, Lehman, \& Russell, 2000). Furthermore, institutions must ensure faculty knowledge of these technological supports for appropriate program and student support (Seels \& Bailey, 1994). 


\section{Administrative Support for Students}

In the United States, with the increase of students attending higher educational institutions since World War II, mechanisms of student support such as health services and cultural activities grew (Barr \& Desler, 2000). In the 1970s, with the influx of a diverse student population, academic services again grew to include counseling, tutoring and childcare (Rentz, 1996). In the 1990s, academic services supplied a range of services involving curriculum support (computer lab, writing center, tutoring), counseling centers and libraries (Bludnicki, 1998; Granger, Daniel \& Benke, 1997).

The functions of student support are both essential and interdependent. It can be argued that student support is primarily seen as an administrative process. The learning environment should create commitment, support students, and enhance self-esteem (Padgett \& Conceao-Runlee, 2000). Although the distance education student is typically a non-traditional student, these student support components continue to be an important element for success.

Distance learners are a qualitatively different, older population, with different educational needs than traditional on-campus undergraduates and graduate students (Dewald, Scholz-Crane, Booth \& Levine, 2000). Compared with more traditional college students, community college 
students are more likely to be "older, employed, have dependents at home, and have interrupted their education" (Brey, 1998, p. 30). To attract these distance education students, institutions should enable distance learners to complete their studies at times and places that are as convenient as possible (Broderick \& Caverly, 1997). Fortunately, the use of the Internet enables students to access education at more convenient locations and times.

Another important aspect of student support is accessibility to educational resources. The dominant feature of distance education is the physical and temporal distance, which separates the teacher and learner (Dewald, Scholz-Crane, Booth, \& Levine, 2000). Because distance students are often placed in a unique situation in which neither teachers nor fellow students are physically present to clarify, discuss, or provide feedback, effective distance education requires a complete learner system (Inman, Elliot, \& Kerwin, 1999). One important means of analyzing the effectiveness of teaching-learning experience in a distance education system is through the analysis of the learner support system (Bludnicki, 1998). "Support systems contribute to the 'process' of a course as do the learning materials" (Hodgson, 1986, p. 56), and support systems developed in recognition of student need help the distance learner become competent and 
self-confident in learning, social interactions and self-assessment (Morris, 1999).

According to Moore and Thompson (1997), the learner support system is comprised of both resources the learner can access in order to carry out the learning process and resources that relate to mediation of the communication process. The resources of the learning process apply to both distance and on-campus students and include the availability of courses, teachers or facilitators, learning materials, library facilities, and technology (Morris, 1999).

Access to library resources is very important for distance students (Clow, 1999). In study by Spooner, Jordon, Algozzine, and Spooner (1999), distance students indicated that success in the course required the use of the library, and the institution should provide access to an on-line library. The Kentucky Virtual University (KVU) was created with passage of the Kentucky Postsecondary Educational Improvement Act of 1997. This partnership plays a critical role in achieving the goals for 2020 outlined in the legislation. In particular, the need to create a postsecondary education system that is accessible, efficient, and responsible to the needs of Kentucky's citizens and economic stakeholders. In this powerful new 
alliance, KCTCS and KVU provide accessible and affordable education and training through:

1. Academic and technical associate degrees.

2. Diploma and certificate programs in occupational fields.

3. Pre-baccalaureate education.

4. Adult, continuing and developmental education

5. Customized training for business and industry.

6. Distance learning opportunities.

Kentucky Community and Technology College System (KCTCS) in partnership with Kentucky Virtual University (KVU) has made services to distance learners a priority within the virtual library, ensuring that remote students are afforded the same access to materials and services that oncampus students enjoy. Additionally, KVU has worked cooperatively with the faculty and staff of KCTCS to facilitate access to a comprehensive portfolio of resources and support services for students at a distance (Young, 2005).

\section{Administrative Support for Providing Appropriate Technology}

In the early 1990s, technology afforded new opportunities for postsecondary students and educational providers to compete via distance learning in a traditional college's service area (Morris, 1999). Community 
colleges have transformed American higher education, replacing elitist traditions with a commitment to change, where that change makes higher education more accessible to countless thousands who otherwise would be excluded from the benefits of post-secondary education (Gaide, 2005).

Technological advances have changed the face of education (Taleb \& Bailey, 1991; Yee, 1998). New digital technologies, such as studentdirected hypermedia programs or large-scale databases accessible through computer networks, promise to transform education in the future (Talab \& Bailey, 1991; Yee, 1998). The use of technology to advance distance education has become much more common at all levels of the educational process. Both teachers and students are tapping into a vast array of human and information resources. The accessibility of technology used to support delivery of curriculum is fundamental to the success of distance education (Sachs, 2005).

As new technologies become more commonplace in the support and delivery of instruction, new questions are raised concerning the effectiveness of traditional pedagogical methods in alternative learning environment (Mioduser, 2000). These technologies have led to the creation of interactive web-based learning that integrates audio materials, graphics, and texts that can enhance the educational interactivity for course delivery and facilitate 
learning for students who are separated form their teachers in time and space (Sachs, 2005). Successful development, implementation and accessibility of distance education courses and programs require collaboration among academic, administrative, technology, and student services units (Dahl, 2004).

The accessibility to, and use of computer technology are of great significance to the process of distance education in that they allow the distance education learners access to extended library resources, career advising, academic advising, financial aid advising, and personal advising. It is the responsibility of the institution to assure adequate technical and physical facilities including appropriate staffing and technical assistance (Dahl, 2004). The availability and convenience of computer word processing for writing assignments as well as for communication purposes help to reduce the sense of a distance learner's isolation (Rentz, 1996).

In a study by Moore and Kearsley (1996), institutional support of technology for online delivery of courses identified the following five factors for success:

1. Access, not only from the perspective of the user being able to access the course site by also access to the system's 
resources, including processing the student's application and access to libraries;

2. Students satisfaction in terms of perceived on-line student support services;

3. Faculty satisfaction including academic integrity, availability of technology to assist in curriculum development; access to technological support for the Blackboard server, and instructional design and consultation for all distance delivery methods;

4. A centralized system provides support for building and maintaining the distance education infrastructure.

The results of a study by Russell (1996) indicated four conclusions concerning institutional support guidelines and appropriate use of common technologies. First, commonly used Internet technologies (e.g., e-mail, Web, FTP, listserv, and IRC) and traditional technologies (e.g., mail, telephone, and fax) are sufficient for delivering a rather technical distance course. Second, among these technologies, fax was the favorite method for submitting assignments, and e-mail was the most used method for communications and dialogues. Third, communication related to the submission of assignments accounted for an outstanding proportion of e- 
mail messages. Fourth, minimal control of technology use helped the instructor and the student's focus on the subject matters, and students achieved high learning performance and satisfaction. Finally, providing unlimited access to technological student services will enhance enrollment, decrease attrition, and provide a well-rounded program. In addition, these key elements ease students’ adjustment to college, assist in their intellectual and personal growth, and contribute to their academic success.

\section{Administrative Support for Providing Appropriate Assessment}

The phenomenal growth of distance-learning programs increased concerns about how to ensure the quality of higher education programs delivered via telecommunications (Gilbert, 1995). The efficacy of technology itself is not in question; research and assessment studies have consistently demonstrated that the achievement and satisfaction of students who learn via technology can equal those of students in regular classrooms. (Johnstone, 2002). Therefore, it is crucial for college leadership to identify, clarify, communicate, and demonstrate their level of commitment to truly become a quality learning community.

Traditionally, teaching has been largely unique and distinctive (Arbaugh, 2000). For example, each faculty member selected the information he or she planned to teach, produced it in the form needed for 
instruction, delivered it in person, devised methods for encouraging students to engage and learn, and then assessed each student' s performance (Arbaugh, 2000). This process involved far more than just the delivery of information, which is a relatively simple task and could well be replaced by a video clip (Ferguson \& Wijekumar, 2000; Sydow, 2000).

Assessments conducted over the past few years have attempted to shed light on the academic rigor of distance education courses by considering factors such as the nature of the different instructional approaches and course content and technology (Clow, 1999; Dillon, Hengst, \& Zoller, 1989). Studies that identify formal program and course assessment are currently missing from the research base, however; quality assessment of basic standards in education and training is currently under debate, especially in terms of its focus and methodology (Inman \& Kerwin, 1999). Regional higher education accrediting agencies are charged with ensuring that distance education programs meet the same standards as oncampus programs. Monitoring the performance of educational institutions is a matter of intensifying significance, and it looms large for the distance learning system (DLS) because of its distinct philosophy, methodology, and approach. 
To make distance learning conducive to effective learning and to ensure its credibility, it is essential for administration to adopt quality assessment procedures information as the basic structure (Dewald, ScholzCrane, Booth, \& Levine, 2000). The most common form of assessment instrument for distance education is a revision of the on-campus instrument already utilized at each institution (Mioduser, 2000). Benchmarks for institutional support and assessment also report distance education program's effectiveness should be assessed through an assessment process that uses several methods and applies specific standards (Simonson, 2005). Data on enrollment, costs, and successful uses of technology should be gathered by administration to assess program effectiveness and intended learning outcomes should be reviewed regularly to ensure clarity, validity and quality (Wade \& Johnson, 2002). These assessment practices should be done at the end of each course and the results should be considered in the ongoing improvement of distance education courses and materials (Gaide, 2005).

\section{Good Teaching Practice by Distance Education Faculty}

\section{Background}

College administrators have increasingly put pressure on faculty to participate in distance learning and other technology related efforts (Trinkle. 
1999). Most faculty, however, have not responded as quickly and enthusiastically as administrators anticipated. A 1998-99 national study of faculty conducted by UCLA’s Higher Education Research Institute (HERI) stated that two thirds of college and university faculty find that keeping abreast of information technology stressful, rating information technology above research/publishing demands, teaching load, and the tenure/promotion as a significant stressor (Trinkle, 1999). Only a small number of researchers have investigated the perceptions of faculty with regard to instructional support, and whether their perceived organizational support has a relationship to faculty’s implementation of good practices Gaide (2005) noted that organizational support of colleges and universities induce strong faculty motivation. From their national faculty survey, Furst-Bowe (1997) concluded that, when faculty judge adequate support exists from facilities and people, their motivation to devote effort to instructional endeavors is high. Rogan (1997) reported faculty commitment was likely to increase to the extent that the university was perceived to provide a supportive environment and an equitable reward system. Among various rewards in higher education institutions designed to induce better teaching, institutional recognition of teaching excellence was the most preferred reward among faculty in higher education (Gaide, 2005). 


\section{Implementation of Appropriate Pedagogy}

The importance of faculty support and training to the success of any distance education or instructional technology effort has been widely acknowledged in the distance education literature. However, minimal attention has been directed to the implementations of good teaching practices.

Faculty members developing distance education courses should approach course design such as curriculum planning, class projects, visual aids, educational materials and student interaction not in terms of replicating the traditional classroom, but in terms of maximizing the potential of the technology that will be utilized (Yee, 1998). Distance education materials such as hardware and software offered by the institution should be implemented within the course design.

It is important that faculty take advantage of the training offered to them by administration to advance their knowledge of technology (Bash, 2005). Faculty may utilize this technology to illustrate or amplify lecture points, and the possibilities for laboratory simulation (Keeton, 2004). Outside the classroom, these materials can also provide adjunct services to the student, supporting drills in such subjects as mathematics, music, design 
and graphics, and language (Arbough, 2000). These uses can substitute for the occasional missed lecture as well.

Faculty teaching distance education courses must also seek the knowledge necessary to implement a quality distance education course (Bash, 2005). The capacity of technology supports a structural change that should remove or at least diminish the old distinctions between residential and off-campus study. Therefore, faculty and administrators must work collaboratively to design the educational resources that students may not have ready access to traditional campus-based resources.

Faculty teaching distance education courses must become proficient in the communications technology employed in their distance education course to maximize student - student interaction and student - teacher interaction (Zirkle \& Guan, 2000).

\section{Student Support by Faculty}

It has been argued that student support is primarily seen as an administrative responsibility, often from the perspective of efficiency. However, where the support of students mediates teaching, good practices have been studied (Arbough, 2000). Bludnicki (1998) reported that the analysis of the student support services included the resources available to 
the learner, the communication process and the communication process characterized by the mechanical and electronic transfer information.

When students are able to participate in a classroom social environment, their preference, and that of the professor, will be for that social experience and setting. However, a stimulating teacher can provide an environment that fosters student-faculty contact and cooperation among students; this encourages collaborative learning and commitment (Olson \& Shershneva, 2004). Frequent student-faculty interaction in and out of classes is the most important factor in student motivation and involvement (Bash, 2005). Prompt feedback by faculty encourages students to continue coursework (Simonson, 2005).

Because good pedagogy encourage active learning, faculty must create an atmosphere that fosters faculty-student interaction as well as student-student interaction (Saba, 2000). Interacting with students via email and telephone are examples of how faculty can utilize technology to increase communication and engage distance learners.

As technology enables institutions to offer distance education courses to students throughout the state, it is important for faculty to offer opportunities for these students to connect with the institution (Carnavale, 2002). Integrating technology into the delivery of any service is not a 
simple process for any faculty member. The resulting services, however, can support students more effectively and efficiently in their quest to be successful learners (Castro, 1999). There are a variety of ways to provide online support for instruction. The following factors have been identified by the Western Interstate Commission for Higher Education (WICHE) as best practice for faculty:

1. Inform students of online tutoring services made available to them by the institution. It is possible to interact with an online tutor in a variety of ways, including via email, chat, or an on-line conference room.

2. Inform students of library services and provide a link within the course website. Include information on how to contact a librarian with special expertise in serving a distance student.

3. Provide information pertaining to self-help materials made available to them through the institution and other college and university links.

4. List and introduce counseling staff on syllabus. To help students who may be reluctant to seek help, include a brief description of each counselor and include contact information. 
5. Provide students with a university guide. To help students feel less isolated this information can the information necessary to contact appropriate personnel within the institution.

6. Provide students with an overview of technical support services available from the institution. Define specific services and eligibility requirements regarding counseling and mentoring services as well as academic advising and tutoring.

The literature is saturated with articles about distance education. These articles address many of the current issues surrounding distance education including hardware and infrastructure, learning outcomes, student attitudes and satisfaction, faculty-student interaction, and virtual communities (Barr \& Dressler, 2000). However, student support services as they relate to distance education programs and the creation of virtual communities seems to be less present.

As outlined by the WICHE, in addition to course development, strategies for the effective use of technology support interaction between students and faculty, active learning, on-line discussion and tutorials, email 
and prompt feedback. In 2000, Saba reported that frequent communication between faculty and student fosters student support and retention.

A controversy within the field of distance education stems from the delivery of distance education and how it affects student support (Ball, Jennie \& Crook, 1997). In a study by Carnivale (2003), simple technology such as fax machines and e-mail were found to be among the most powerful tools for communicating with distance students. These technologies give continuous access to students and provide for rapid asynchronous communication between university instructors and teachers.

\section{Faculty Implementation of Technology}

Distance education has become increasingly common, owing to the extremely rapid expansion of distance education technologies. These technologies have been evolving from traditional technologies such as mail, telephone, and fax, to instructional design and computer systems such as the Internet (Russell, 1999). Although there are many suggestions for how to use technology to deliver distance courses, few studies report the underlying issues such as learner characteristics and needs, the influence of technology upon the instructional process, equity of access to interactive delivery systems, and the new roles of teacher (Dahl, 2004). 
It is the distance education student whose access is dramatically improved by technology. These off-campus students are most likely to benefit qualitatively from the resources and interactive capacities provided by technology (Arbough, 2000). They are the students who cannot participate routinely in the classroom. Nor can they visit the library or learning resources facility with ease. For these students, educational technology can provide access, convenience, flexibility, and pedagogy (Sydow, 2000). For many, it may well provide the only way they are to become active students.

Appropriate use of technology by faculty is important for distance education courses to be effective (Bash, 2005). The technology used must utilize good teaching strategies and be easily accessible to distance learners and employ appropriate resources for the required curriculum (Morris, 1999). A well-conceived distance education program can fit squarely within a structured curriculum. This structured curriculum should include clear leaning objectives as a useful framework for the course’s content, activities, and learning assessments (Padgett \& Conceao-Runlee, 2000).

With technology, the best faculty specialists are accessible, the most extensive library and data resources can be delivered, and direct, regular student and faculty interaction is possible anywhere, at any time (Lorenzetti, 
2004). Although faculty is utilizing technology in classroom instruction with increasing frequency, technology remains, for the most part, a sometime addition to the professor (Lorenzetti, 2004).

While faculty have done a remarkable job of integrating technology into their distance education courses and academic programs, this integration has been independent of the development of student support (Arbough, 2000). With rare exceptions, student support services have remained on the sidelines in terms of issues related to servicing distance students. Distance students, like resident and commuter students deserve the attention of faculty to include student services into their curriculum (Zirkle \& Guan, 2000)

\section{Assessment Course Quality by Faculty}

Assessment and assessment play an important role in legitimizing the distance education process to ensure that each course is consistent with the academic program’s curriculum (Russell, 1999). Faculty who opt to teach distance learners should periodically review each course for currency of content, the use of the appropriate technology, and the effectiveness of the delivery strategies (Arbough, 2000). Identifying and understanding the elements to assess is more complex in distance education for general elements as well as for specific ones (Bar \& Dressler. 2000). When compared to traditional learning, there are more elements to take into 
account in the Assessment process. This is due to flexibility of distance education, along with the wider range of resources provided to students (Carnevale, 2002).

To assure quality in distance education, a new type of university teacher must evolve (Svetcov, 2000). To determine course effectiveness, distance education teachers use a variety of assessment tools. For example, to assess the effectiveness of their course, most teachers survey distance learners of completed courses to poll their opinions of the course (Saba, 2000). These surveys address questions pertaining to issues such as clarity of course content, appropriateness of assignments, and teaching effectiveness (Morris, 1999). The goal is to assess overall effectiveness of the completed course, which can be a springboard in developing a revision plan (Bar \& Dressler, 2000). The current literature on assessing online courses identifies two aspects of particular significance. The first step in evaluating course design is the assessment of learning, and the second is of the participant's performance, both in terms of time spent online and activities effectively carried out at a distance, either individually or during computer conferencing (Ching, 1998).

The challenge for planners and designers is to determine how they can use online techniques for assessment strategies (Zuckerman, 2005) and at the 
same time not replicate those strategies designed for the face-to face environment. Assessment can be teacher, peer or student directed and within that context the way in which assessment items are presented becomes critical. Professors should establish criteria for evaluating students' efforts in online discussions and communicate those criteria to students (Saba, 2005). Professors sometimes assume that criteria and standards for assessment are self-evident which is problematic. When professors fail to communicate standards for participation, students have no choice but to revert to their own past experiences to help them define acceptable levels of performance (Barab \& Duffy, 2003). Therefore, it is the faculty's responsibility to establish clear criteria that can serve as the basis of assessment (Young, 2000).

\section{Summary}

This chapter describes numerous best practices strategies and guidelines by WICHE for designing distance education programs. Because information technology and the use of electronic information systems have changed the world of postsecondary education at a rate never before experienced, guidelines based on these best practices are crucial for distance education programs. Originally, distance education was initiated as an inexpensive way for rural community colleges to increase course offerings, 
rapidly changed with the potential for electronic information transmission.

In general, its success has been attributed to access to the best instructors and educational resources. The following chapter will explain the components of the study as well as the research instrument. 


\section{Chapter III}

\section{Methods}

The purpose of this study was to analyze the relationship, if any, between faculty perceptions of administrative support for distance education and the levels of implementation of good distance education teaching practices as perceived by the faculty of rural community colleges. The study investigated faculty perceptions of institutional support for distance learning and the implementation of good distance education teaching practices as perceived by the faculty of the Kentucky Community and Technical College System (KCTCS). KCTCS is of interest because of The Post-secondary Education Improvement Act of 1997, which assigned access to quality education programs and data is easily accessible. In order to meet this objective, KCTCS collaborated with the consulting company, Western Insterstate Commission for Higher Education (WICHE) to provide quality post-secondary education through distance education programs. WICHE provided guidelines on the delivery of quality distance education programs. The teaching practices are also based on the Principles of Good Practice for Electronically Delivered Academic Degree and Certificate Programs developed by the WICHE. The following research questions, which are based on faculty perceptions, were investigated: 
Q1. What is the relationship between the faculty perceived level of administrative support for faculty and faculty implementation of good distance education teaching practices?

Q2. What is the relationship between faculty perceived level of administrative support for students involved in distance education and faculty implementation of good distance education teaching practices?

Q3. What is the relationship between the faculty perceived level of administrative support for technology and faculty implementation of good distance education teaching practices?

Q4. What is the relationship between the faculty perceived level of appropriateness of distance education assessment policies and the implementation of good distance education teaching practices?

In order to provide a meaningful assessment, this study were analyzed the faculty's perceptions of administrative support of faculty, students, technology and assessment of the distance education program and were attempted to correlate these factors with faculty's perception of implementation of good teaching practices based on the Principles of Good Practice for Electronically Delivered Academic Degree and Certificate Programs. This chapter includes a description of the research design, the 
target population, they survey instrument and an overview of the data analysis procedures that were utilized.

\section{Research Design}

The study used a comparison design that included a survey to generate quantitative data for analysis. Because the independent variables were not manipulated, comparison research design helped to identify the dependent variables. The purpose of this research design was to gather information that will identify the relationship, if any, between the faculty perceived level of administrative support for faculty, students, technology and assessment of distance education programs and the implementation of good teaching practices as perceived by faculty.

\section{Population}

The population for this study was the full-time distance education faculty ( $\mathrm{N}=432$ ) who taught complete web-based courses in the Kentucky Community and Technology College System (KCTCS) during the 20052006 school year. The target institutions were Ashland Community and Technical College, Big Sandy Community and Technical College, Bluegrass Community and Technical College District, Bowling Green Technical College, Elizabeth Community and Technical College, Gateway Community and Technical, Hazard Community and Technical College, Henderson 
Community College, Hopkinsville Community College, Jefferson

Community and Technical College District, Madison Community College, Maysville Community and Technical College, Owensboro Community and Technical College, Somerset Community College, Southeast Kentucky Community and Technical College, and West Kentucky Community and Technical College. These institutions comprise the KCTCS.

\section{Instrumentation}

To measure faculty perception on administrative support for distance education, the survey was designed with 10 items on a 5-point Likert scale from "Very High Level” (5) to "Very Low Level” (1). Institutional support includes the following independent variables for this study: faculty support, student support, technology and assessment (Barab \& Duffy, 2000). Survey items 1-2 address institutional implementation of faculty support by administration. Survey items 3-5 address implementation of student support by administration. Survey items 6-7 address implementation of technological support by administration and items 8-9 address implementation of assessment policies by administration. To measure faculty perception on implementation of appropriate pedagogy, the survey was designed with 12 items on a 5-point Likert scale from "Very High Level" (4) to "Very Low Level" (1). To measure the implementation of best 
teaching practices by faculty items 10-11 address appropriate pedagogy.

Items 12-13 address student support by faculty, items $14-15$ address appropriate use of technology and items 16-18 address support for assessment by faculty. A mean was calculated for all survey items and was used as a score for the implementation of Best Distance Education Teaching Practices.

The survey instrument was pilot tested by administering it to an expert panel at Marshall University. The survey was revised based on feedback from these expert panel members. The structured, forced-choice, Faculty Perceptions of Institution Putting Principles into Practices survey questions for faculty to address the following areas: faculty perceptions of institutional implementation of faculty support, faculty perceptions of institutional implementation of student support, faculty perceptions of institutional implementation of technological support and faculty perceptions of institutional assessment of distance education program(s). The survey was designed to be completed by faculty who teach complete web-based courses.

\section{Collection of Data}

The researcher contacted the KCTCS distance education representative for contact information for the full-time distance education 
faculty. An individual e-mail message was sent by the KCTCS

administration to each faculty member on the contact list to ask him or her to participate in the survey. All of the potential subjects received an additional email explaining the purpose of evaluating faculty perception and informing them of the email address to which the survey questionnaire should be returned.

This study consisted of an emailed survey that was administered Spring 2006 to the full-time faculty members of the distance education program at KCTCS. Responses were sought from16 community colleges with a targeted response rate of at least 51\% (Keringer \& Lee, 2000).

After gathering faculty perception data, the researcher collected the information from the survey instruments to compile information concerning issues of administrative support for distance education and faculty implementation of appropriate pedagogy.

\section{Data Analysis}

The perceptual data was analyzed by descriptive analysis to explain the quantitative date collected (Kerlinger \& Lee, 2000). Inferential techniques determined the differences in perceptions of distance education faculty among variables to see if institutional support is correlated with good 
distance education teaching practices. Because the subjects in this study are independent of one another, there were no matching of subjects or other control procedures used.

Frequency distributions were obtained for the demographic variables of this study and assisted in the interpretation of a collection of data by arranging measures of a given variable to determine the frequency of occurrence of the different values. Correlation analysis supported the relationship, if any, between the variables. The purpose of this type of research is to identify the relationship among variables. 


\section{CHAPTER IV}

\section{Analysis of Data}

This study investigated faculty perceptions of administrative support for distance education and the levels of implementation of good distance education teaching practices as perceived by the faculty of rural community colleges in Kentucky. To investigate the issue, the study applied a survey research methodology using a comparison design. The survey was completed by faculty who teach distance education courses at Kentucky Community and Technology College System (KCTCS).

An individual e-mail message was sent to each person on a list of KCTCS faculty asking them to participate in the survey. All the population received additional information explaining the purpose of the survey and informing them of the e-mail address where the completed survey should be submitted. A total of 331 out of 432 faculty from 15 institutions responded to the survey. The final response rate was $76 \%$.

The independent variables were faculty perception of administrative faculty support, student support, technological support, and support for assessment. The dependent variable was faculty perceived good teaching practices in distance education. 


\section{Findings}

Data were gathered using the researcher-developed Faculty Perceptions of Institution Putting Principles into Practices Survey (FPIPPS). The FPIPPS consisted of 18 items derived from the distance education literature. Respondents were asked to rate each item using a 5-point Likert type scale ranging from "very low" to "very high". The following paragraphs discuss the findings for each research question.

Research Question 1: What is the relationship between the faculty perceived level of administrative support for faculty and faculty implementation of good distance education teaching practices?

A score for the perceived level of administrative support for faculty, the independent variable, was calculated as a mean of the responses to survey items 1 and 2. Similarly, a score for the dependent variable, implementation of good teaching practices, was calculated as a mean of responses to survey items 10-18. a Pearson's Correlation analysis was performed, comparing the scores obtained for the variable. As indicated in Table 1, a significant positive correlation value ( $\mathrm{r}$ $=.133$ ) existed between the two scores. This means that as respondents perceived a higher level of administrative support for faculty they also reported an increase in their use of good distance education teaching practices. Conversely, when the perception of support was lower, the reported use of good distance education 
teaching practices was lower. The significance of this correlation score $(r=.133)$ is indicative of a true relationship between the variables.

Research Question 2: What is the relationship between faculty perceived level of administrative support for students involved in distance education and faculty implementation of good distance education teaching practices?

A score for the perceived level of the independent variable, administrative support for students, was calculated as a mean of the responses to survey items 3-5. A score for the dependent variable, implementation of good teaching practices, was calculated as a mean of the numerical sum of survey items 10-18. A Pearson's Correlation analysis was performed, comparing the scores obtained for the variables. As indicated in Table 1, the a significance positive correlation value $(\mathrm{r}=$ .123), existed between the two scores. Therefore, as respondents perceived a higher level of administrative support for students, they also reported an increase in their use of good distance education teaching practices. However, when the perception of support was lower, the reported use of good distance education teaching practices was lower. The significance of this correlation score $(r=.123)$ is indicative of a true relationship between the variables.

Research Question 3: What is the relationship between the faculty perceived level of administrative support for technology and faculty implementation of good distance education teaching practices? 
A score for the perceived level of the independent variable, administrative support for technology, was calculated as a mean of the responses to survey items 6 and 7. A score for the dependent variable, implementation of good teaching practices, was calculated as a mean of the numerical sum of the survey items 1018. The result was not significant at the alpha level of 0.01 as displayed in table 1 . Therefore, there is no significant relationship between faculty perception of administrative support for technology and good distance education teaching practice. This means that as respondents perceived a higher level of administrative support for technology. However, there was no significant corresponding change in teaching practices.

Research Question 4: What is the relationship between the faculty perceived level of appropriate distance education assessment policies and the implementation of good distance education teaching practice?

A score for the perceived level of the independent variable, administrative support for assessment was calculated as a mean of the responses to survey items 8 and 9. A score for the dependent variable, good teaching practices, was calculated as a mean of the numerical sum of survey items 10-18. A Pearson's Correlation analysis was performed, comparing the scores obtained for the variables. As indicated in Table 1, a significant positive correlation value $(\mathrm{r}=.196)$ existed between the two scores. This means that as respondents perceived a higher level of 
administrative support for assessment, they also reported an increase in their use of good distance education reaching practices. However, when the perception of support was lower, the reported use of good distance education teaching practices was lower. The significance of this correlation score $(r=.196)$ is indicative of a true relationship between the variables.

\section{Table 1}

Correlations Between Administrative Support and Faculty Implementation of Good Distance Education Teaching Practice

\begin{tabular}{lccc}
\hline & \multicolumn{2}{c}{ Good Distance Ed Teaching Practice } \\
\hline & $\begin{array}{c}\text { Pearson } \\
\text { Correlation }\end{array}$ & Sig. (2-tailed) & $\mathrm{N}$ \\
\hline Administrative Support for Faculty & .133 & .063 & 331 \\
Administrative Support for Students & $.123^{*}$ & .026 & 331 \\
Administrative Support for Technology & .109 & .065 & 331 \\
Administrative Support for Assessment & $.196 * *$ & & \\
\hline * Correlation is significant at the 0.05 level (2-tailed) & & \\
$* *$ Correlation is significant at the 0.01 level (2-tailed) &
\end{tabular}

\section{Summary}

This study investigated faculty perceptions of administrative support for distance education, and whether faculty implementation of good distance education teaching practice has a relationship with administrative support. A summary of the findings reveled that the dependent variable, good distance education teaching 
practice, significantly correlated to all of the independents variable with the exception of administrative support for technology. This means that as the faculty of KCTCS perceived higher levels of support by their college's administration for faculty, students and assessment, their perception of their use of distance education teaching practices also increase. Conversely, as they perceived a diminished support for these factors, the perception of their use of good distance education teaching practices decreased. The only factor that did not have a significant correlation with good distance education teaching practice was the perception of the administrative support for technology. 


\section{CHAPTER V}

This chapter includes the purpose of the study, a summary of the procedures used, and a summary of the data. Summaries of the study's findings and conclusions are then presented. The chapter closes with implications of the study and recommendations for further research.

\section{Summary of the Study}

The purpose of this study was to analyze the relationship between faculty perceptions of administrative support for distance education and the levels of implementation of appropriate pedagogy as perceived by the faculty of rural community colleges in Kentucky. To investigate the issue, the study used research methods gather perceptual data from faculty at KCTCS who teach distance education courses at KCTCS.

\section{Findings and Conclusions}

A summary of the findings reveal that the dependent variable, good distance education teaching practice, had a positive significant correlation with all of the independent variables, except of administrative support for the technology variable. This means that as the faculty of KCTCS perceived higher levels of support by the colleges administration for faculty, students and assessment, their perception of their use of distance education teaching practices also increase. Conversely, as they perceived a diminished support for these factors, the 
perception of their use of good distance education teaching practices decreased. The faculty perception of administrative support for technology indicated no relationship existed.

Research Question 1: What is the relationship between the faculty perceived level of administrative support for faculty and faculty implementation of good distance education teaching practices?

A score for the perceived level of administrative support for faculty, the independent variable, was calculated as a mean of the responses to survey items 1 and 2. Similarly, a score for the dependent variable, implementation of good teaching practices, was calculated as a mean of responses to survey items 10-18. a Pearson's Correlation analysis was performed, comparing the scores obtained for the variable. As indicated in Table 1, a significant positive correlation value ( $\mathrm{r}$ $=.133$ ) existed between the two scores. This means that as respondents perceived a higher level of administrative support for faculty they also reported an increase in their use of good distance education teaching practices. Conversely, when the perception of support was lower, the reported use of good distance education teaching practices was lower. The significance of this correlation score $(r=.133)$ is indicative of a true relationship between the variables. These responses are in concordance with those found in a 2002 study by Rockwell, Schauer, Fritz, and Marx, where the institutional support given to faculty to develop instructional 
materials that blend technology and utilize mediated information and instruction was reported as being very important to the success of distance education courses.

Research Question 2: What is the relationship between faculty perceived level of administrative support for students involved in distance education and faculty implementation of good distance education teaching practices?

A score for the perceived level of the independent variable, administrative support for students, was calculated as a mean of the responses to survey items 3-5. A score for the dependent variable, implementation of good teaching practices, was calculated as a mean of the numerical sum of survey items 10-18. A Pearson's Correlation analysis was performed, comparing the scores obtained for the variables. As indicated in Table 1 , the a significance positive correlation value $(\mathrm{r}=$ .123), existed between the two scores. Therefore, as respondents perceived a higher level of administrative support for students, they also reported an increase in their use of good distance education teaching practices. However, when the perception of support was lower, the reported use of good distance education teaching practices was lower. The significance of this correlation score $(r=.123)$ is indicative of a true relationship between the variables. These conclusions support the research by Arbough (2000) that quality distant learning environments are created when faculty implement appropriate technology, provide timely feedback, and inform students of support services. 
Research Question 3: What is the relationship between the faculty perceived level of administrative support for technology and faculty implementation of good distance education teaching practices?

A score for the perceived level of the independent variable, administrative support for technology, was calculated as a mean of the responses to survey items 6 and 7. A score for the dependent variable, implementation of good teaching practices, was calculated as a mean of the numerical sum of the survey items 1018. The result was not significant at the alpha level of 0.05 as displayed in table 1 . Therefore, there is no significant relationship between faculty perception of administrative support for technology and good distance education teaching practice. This means that as respondents perceived a higher level of administrative support for technology, there was no significant corresponding change in teaching practices. These responses support the notion of Care and Scanlan (2001) that for administrators, creating and conveying technological visions powerful enough to displace traditional educational models is one of the most challenging aspects of leadership. Although faculty tend to hold a positive view regarding technology, they do not implement technology into their program.

Research Question 4: What is the relationship between the faculty perceived level of appropriate distance education assessment policies and the implementation of good distance education teaching practice? 
A score for the perceived level of the independent variable, administrative support for assessment, was calculated as a mean of the responses to survey items 8 and 9. A score for the dependent variable, good teaching practices, was calculated as a mean of the numerical sum of survey items 10-18. A Pearson’s Correlation analysis was performed, comparing the scores obtained for the variables. As indicated in Table 1, a significant positive correlation value $(\mathrm{r}=.196)$ existed between the two scores. This means that as respondents perceived a higher level of administrative support for assessment, they also reported an increase in their use of good distance education reaching practices. However, when the perception of support was lower, the reported use of good distance education teaching practices was lower. The significance of this correlation score $(r=.196)$ is indicative of a true relationship between the variables. This correlation supports the research by Zuckerman (2005) which found that it is important that administration evaluate the program's or course's education effectiveness, including assessments of student learning, outcomes, and faculty satisfaction. Without this type of support, the quality of distance education teaching practice is compromised (Saba, 2005). 


\section{Discussion}

While the objective of this research has been to compare the relationship between institutional support and faculty implementation of good distance education teaching practice, there are many factors that contribute to a successful distance education program. This study adds to the body of knowledge for distance education by making a significant contribution in research focused on administrative support for faculty in distance education.

Saba (2005) indicated that faculty perception is the most critical attribute influence the use of distance education. Dillon and Walsh (1992) argued that distance education, when viewed as an innovation, will provide valuable insight to understanding faculty perceptions when choosing to adopt or reject it as an innovative approach to education. Regardless of the mode of delivery, the quality of a distance education program is the responsibility of distance education faculty (Saba, 2005). However, the majority of faculty are unprepared to effectively teach in a technology dominated area (Padgett \& Conceao-Runlee, 2000). A key to implementing successful distance education is the integration of administrative support and faculty support. In this study, faculty perceived the level of administrative support for technology as high. However, as supported by the literature, 
faculty reported they did not take advantage of this type of support. This theory aligns with Calvert's (2005) work suggesting that although administrators provide technological training for distance education faculty, these faculty members do not often take advantage of this type of support.

It appears that with the exception of technology, faculty perceive that they implement a high level of good distance education teaching practice when the level of support from administration is also high. This finding supports the research by Simonson (2005) which revealed that providing faculty support for distance education is the logical step in providing quality distance education programs.

Ultimately, distance education is an opportunity for meaningful involvement, professional development, and administrative support that are the key factors in promoting faculty implementation of good distance education teaching practices and significant contributions to the distance education process. For distance learning to be implemented in higher education, the adage of "if you build it, they will come" is not the most critical variable (Deed, 1996). Although building an infrastructure for distance learning is a difficult task, the key to successful implementation is the faculty who will deliver the courses. Faculty must perceive that teaching 
and learning at a distance will meet both student and faculty needs (Bash, 2005).

\section{Implications}

A successful distance education program should have support systems in place for faculty and students. Institutional support for faculty involved in distance education is essential and should take a variety of forms to recognize the range of motivations and needs of faculty as well as distant learners (Bash, 2005). This type of informative support typically comes from specialists such as instructional designers, editors, technicians, graphic designers, and librarians (Gaide, 2005). In a distance education environment, instructional support should take the forms of course redesign support, training in the use and application of distance education technologies, technical support, as well as student services and assessment guidelines (Sachs, 2004).

Distance education is new to many faculty members and students. Therefore, faculty members and students may be intimidated by technology and distance education. Learning new techniques to incorporate new technology into the classroom is not always and easy task. There is limited technical support, and there is little motivation or reward for the faculty to 
make the effort. Support for these participants to enable them to design and develop distance courses as well as technical support to help them to run the technologies, is needed to support the development and delivery of quality distant education courses. Institutions need to develop the infrastructure to provide training, technical support, time for the faculty to develop the course, and a revised faculty reward system.

Each course of study should result in learning outcomes appropriate to the rigor of the degree rewarded. The course should provide for appropriate interaction between faculty and students and be consistent with the institution's role and mission. The functions of student support are both essential and interdependent. The learning environment should create commitment, support students, and enhance self-esteem (Padgett \& Conceao-Runlee, 2000). Students should be provided with clear and complete information regarding curriculum, course requirements, academic support services, and technological support services. Appropriate use of technology by faculty is important for distance education courses to be effective (Bash, 2005). The technology used must utilize good teaching strategies and be easily accessible to distance learners and employ appropriate resources for the required curriculum (Morris, 1999). A wellconceived distance education program can fit squarely within a structured 
curriculum. This structured curriculum should include clear leaning objectives as a useful framework for the course's content, activities, and learning assessments (Padgett \& Conceao-Runlee, 2000).

To make distance learning conducive to effective learning and to ensure its credibility, it is essential for administration to adopt quality assessment procedures information as the basic structure (Dewald, ScholzCrane, Booth, \& Levine, 2000). The most common form of assessment instrument for distance education is a revision of the on-campus instrument already utilized at each institution (Mioduser, 2000). Benchmarks for institutional support and assessment also report distance education program's effectiveness should be assessed through an assessment process that uses several methods and applies specific standards (Simonson, 2005). Data on enrollment, costs, and successful uses of technology should be gathered by administration to assess program effectiveness and intended learning outcomes should be reviewed regularly to ensure clarity, validity and quality (Wade \& Johnson, 2002). These assessment practices should be done at the end of each course and the results should be considered in the ongoing improvement of distance education courses and materials (Gaide, 2005). 


\section{Recommendations}

The implementation of distance education courses must be a collaborative effort between administration and faculty. Therefore, more information is needed to (a) identify motivational factors of the distance education faculty member; (b) further investigate the various concerns addressed by administration and faculty of distance education, and (c) elaborate on how leadership responsibilities at each level of support or hinder the delivery of quality distance education programs. 


\section{References}

Arbaugh, J. B. (2000). Virtual classroom versus physical classroom: An exploratory study of class discussion and student learning in an asynchronous internet-based MBA course. Journal of Management Education, 24, 213-246.

Bailey, C., \& Chambers, J. (1996). Interactive learning and technology in the US sciences and mathematic reform movement. British Journal of Educational Technology, 27, 123-133.

Ball, Jennie, \& Crook, B. (1997). Managing Change through distance learning. Community College Journal of Research and Practice, 21, 13-22.

Barab \& Duffy (2003). Using emerging technologies to help bridge the gap between university theory and classroom practice. Educational Technology Research, 9, 12, 22-53.

Barr \& Desler (2000). The handbook of student affairs. San Francisco,CA: Jossey-Bass.

Bash (2005). Best practices in adult learning. Distance Education Report, 9, 18,6-12.

Beaudoin, M. (1990). The instructor's changing role in distance 
education. American Journal of Distance Education, 4, 21-29.

Berenfeld, B. (1996). Linking students to the infoshere. T.H.E.

Journal, 4, 76.

Bludnicki, M. (1998). Supporting virtual learning for adult students.

T.H.E. Journal, 25, p. 73-76.

Brey, R. (1988). Expanding the classroom through technology:

Meeting the Mission of Community Colleges. Community,

Technical, and Junior College Journal, 58, 29-31.

Broderick, B. \& Caverly, D. C. (1998). Techtalk: Distance

developmental education. Journal of Developmental

Education, 21(3), 36-39.

Broderick, B. \& Caverly, D.C. (1997). Websites for developmental

students. Journal of Developmental Education, 21(3), 36-39.

Burnett, S. (2001). Going the Distance. Community College Weekly, 13, 36-42.

Calvert (2005). Distance education at the crossroads. Distance Education, 26, 2, 255-272.

Campbell, D. (2000). Commitment to quality: There from the beginning. Community College Journal of Research and Practice, 24,1. 
Carnivale, D. (2002). Union seeks agreement with University of Massachusetts on distance education. Chronicle of Higher Education, 49, 5, 50.

Carnivale, D. (2003). How to succeed in distance education. Chronicle of Higher Education, 49, 40, 31-33.

Castro, C. (1999). An analysis of the perceptions of community college leaders regarding good practices at New Jersey community colleges. Unpublished doctoral dissertation, University of Sarasota, Florida.

Caverly, D., \& MacDonald, L. (1998). Techtalk: Distance developmental education. Journal of Developmental Education, 21(3), 36-39.

Ching, L. (1998). The Influence of a Distance-Learning. Journal of Experimental Education, 66, 149.

Clow, K. (1999). Interactive distance learning: Impact on student course assessments. Journal of Marketing Education, 21(2), 97-106.

Dahl, J. (2004). Creating comfort zones for best practices. Distance Education Report, 8, 9, 1-4.

Dahl, J. (2004). Focus on collaboration and the technology will 
follow. Distance Education Report, 8, 15, 5-6.

Dahl, K. (2005). Boosting faculty participation in support activities. Distance Education Report, 9. 4-7.

Dede, C. (1996). The evolution of distance: Emerging technologies and distributed learning. American Journal of Distance Education, 10(2), 4-36.

Dennis, M. (2003). Nine higher education mega-trends, and how they'll affect you. Distance Education Report, 7, 24, 6.

Dewald, N.,Scholz-Crane, A., Booth, A. \& Levine, C. (2000). Information literacy at a distance: Instructional design issues. Journal of Academic Librarianship, 26, 33-45.

Dillon, C., Hanegst, \& Zoller, D. (1989). Instructional strategies, distance education and student involvement. Journal of Education for Business, 72(2), 74-78.

Dillion, C.L. \& Walsch, S.M. (1992). Faculty: The neglected resources in distance education. The American Journal of Distance Education, 6, p.5-21.

Easterday, N. (1997). Distance education and 2-year colleges. Community College Journal of Research and Practices, 21, 2326. 
Eddy, J., George, J., Spaulding, D., \& Murphy, S. (1997).

Technology assisted education. Education, 117, 478-480.

Ferguson, L. Wijekumar, K. (2000). Effective design \& use of webbased distance learning environments. Professional Safety, 45(1), 28-33.

Furst-Bowe, J.A. (1997). Comparison of student reactions in traditional and videoconferencing courses in training and development. International Journal of Instructional Media, 24(3), 197-206.

Gaide, Susan (2005). Best practices for helping students complete online degree programs. Distance Education Report, 8, 20, 8

Gaide, Susan (2005). Increase retention by establishing institutional and faculty benchmarks. Distance Education Report, 9, 15-19.

Ganzel, R. (1999). What price on-line learning. Training, 3, 54.

Gilbert, S. (1995). Teaching, learning, \& technology. Change, 27(2), 46-53.

Granger \& Benke (1997). Supporting students at a distance. Adult Learning, 7(1), pp. 22-23.

Granger, D. (1990). Open universities. Change, 22, 44.

Gulick, L., \& Urwick, L. (Eds.) (1937). Papers on the science of 
administration. New York: Columbia University Press.

Hains, A., Belland, J., Conceicao-Runlee, S., Santos, R., Milagros, \&

Rothenberg, D. (2000). Instructional technology and personnel preparation. Topics in Early Childhood Special Education, 20(3), 132-145.

Hains, A.H. Conceicao-Runlee, S., Carol, P. \& Marchel, M.A. (1999). Collaborative course development in early childhood special education through distance learning. Research \& Practice, 14(1), 12-15.

Hassenplug, C. \& Harnish, D. (1998). The nature and importance of interaction in distance education credit classes at technical institutes. Community College Journal of Research \& Practice, 22, 591-606.

Hodgson, P. (1999). How to teach cyberspace. Techniques: Making Education and Career Connections, 74, p.33.

Inman, E. \& Kerwin, M. (1999). Instructor and student attitudes toward distance learning. Community College Journal of Research and Practice, 23, p.581

Interregional Committee on Distance Learning (1997). Definition and 
guidelines for distance education. Philadelphia, PA:

Commission of Higher Education Middle States Association of Colleges and Schools.

Johnstone, S. (1996). Some principles of good practice for the virtual university. Change, 28, $\underline{38}$.

Johnstone, S. (2002). Class participation and the whites of their eyes. Syllabus, 15(11), 20.

Kalke, N.L., Macy, J.A., \& Rooney, R.H. (1998). Providing effective education in distance education. Journal of Social Work Education, 34, 71-80.

Karayan, S.S. (1997). Student perceptions of electronic discussion Groups. T H E Journal, 24, 69.

Keeton, M. (2004). Best online instructional practices: Report of Phase I of an ongoing study. Distance Education Report, 8, 21, 8.

Kirk, E. (1999). Libraries close in on distance education. Library Journal, 124, 40.

Levin, B. (1999). Analysis of the content and purpose of four different kinds of electronic communications among teachers. Journal of Educational Computing Research, 21, 1, 139-56. 
Lorenzetti, J. (2004). Why greater accessibility is better for everyone.

Distance Education Report, 8, 14, 1-7.

McCall (2005). Distance Education Expansion for Kentucky

Community and Technological Systems. The Exchange, 8, 2, 3-5.

Mioduser, D. (2000). Web-based learning environment: Current pedagogical and technology state. Journal Research on Computing in Education, 33, 55.

Moore, M.G. \& Thompson, M.N. (1997). The effects of distance learning (Rev.ed). (ACSDE research Monograph No. 15). University Park: The Pennsylvania State University, American Center for the Study of Distance Education.

Moore, M.G., \& Kearsley, G. (1996). Distance education: A systems view. New York: Wadworth.

Morris, K. (1999). Wiring the ivory tower. Business Week, 90-94.

National Center for Education Statistics (October, 1997) Distance Education in Higher Education, http://nces.ed.gov/pubs98/distance/index.html, accessed 3 August 2000.

Newby, T.J., Stepich, D.A., Lehman, J.D., \& Russell, J.D. (2000). 
Instructional technology for teaching and learning: Designing instruction, integrating computers, and using media ( $2^{\text {nd }}$ ed.). Upper Saddle River, NJ: Merrill/Prentice Hall.

Olson \& Shershneva (2004). Setting quality standards for web-based continuing medical education. Journal of Continuing Education, 24, 2, 100-111.

Padgett, D. \& Conceao-Runlee, S. (2000). Designing a faculty development program on technology: If you build it, will they come? Journal of Social Work Education, 36(2), 325-335.

Rentz, A. (1996). Student affairs practice in higher education. (Rev.ed.). Springfield, IL: Thomas.

Rogan, J.M. (1997). Online mentoring: Reflections and suggestions. Journal of Computing in Teacher Education, 13(35), 5-13.

Rising, L. \& Watson, J.E. (1998). Improving quality and productivity in training: A new model for the high-tech learning environment. Bell Labs Technical Journal,_3(1), 134-144.

Russell, T.L. (1999). The no significant difference phenomenon. Raleigh: North Carolina University. http://nova.teleeducation.nb.

Saba, F. (2000). Evaluating distance education programs. Distance 
Education, 4(4),1.

Saba (2005). Critical issues in distance education. Distance

Education, 26, 2, 255-272.

Sachs, S. (2004). Institutional issues when distance learning joins the mainstream. New Directions for Community Colleges, 128, 2330.

Seigal, E., Jennings, J.G., Conklin, J., \& Napoletano Flynn, S.S. (1998). Distance learning in social work education: Results and implications of a national survey. Journal of Social Work Education, 34, pp.45-60.

Simonson, Michael (2005). Entering the mainstream. Quarterly Review of Distance Education, 6, 1,1.

Smith (2005). Distance education : Past contributions and possible futures. Distance Education, 26, 2, 159-163.

Spooner, F., Jordon, L., Algozzine, B., \& Spooner, M. (1999).

Student ratings of instruction in distance learning and oncampus classes. Journal of Educational Research, 92, p.132.

Sydow, D. (2000). Long-term investment in professional 
development: Real dividends in teaching and learning.

Community College Journal of Research \& Practice, 24(5), pp.383-398.

Svetcov, D. (2000). The virtual classroom vs. the real one. Forbes, $166,7,50-54$.

Trinkle, D. A. (1999). Distance education: A means to an end, no more, no less. Chronicle of Higher Education, 45(48), 60-64.

Talab, R. \& Bailey, G. (1991). Copyright, licensing and contractual issues in distance education course delivery. Tech Trends, 36, p. 63.

Wade, W. \& Johnson, R. (2002, September). Report to the 2002 CLIK conference. University of Kentucky, Lexington, KY.

Watson, B. (1990). The wired classroom: American education goes online. Phi Delta Kappa, 72(2), 109-112.

Yee, J. (1998). Distance learning and community colleges. CommunityCollege Journal of Research and Practice, 22, p.563.

Young, J.R. (1997). Rethinking the role of the professor in an age of high-tech tools. The Chronicle of Higher Education, 44, A26A28. 
Young, J.R. (1999). Kentucky’s virtual will serve as an on-line course catalogue. Chronicle of Higher Education, 46, 2, 52.

Young, J. (2000). Distance education transforms help desks into '247' operations. Chronicle of Higher Education, 46, 38, 49-52.

Zhang, P. (1998). A case study use on technology use in distance education. Journal of Research on Computing in Education, 30, p.32.

Zirkle, C. \& Guan, S. (2000). The journey into distance education. Techniques: Connecting Education \& Careers, 75(5), 18-22. Zuckerman (2005). Classroom revolution. News and World Report, 139, 13, 68. 
APPENDIX A

SURVEY COVER LETTER MAILED TO DISTANCE

EDUCATION FACULTY AT KCTCS

Dear Faculty,

You have been selected to participate in this research study because of your involvement in distance education at Kentucky Community \& Technical College System (KCTCS). You participation is voluntary. You have the right not to participate and also the right not to answer all of the questions. The purpose of this study is to analyze the relationship between faculty perceptions of administrative support for distance education and the levels of implementation of appropriate pedagogy as perceived by the faculty of a rural community college. Results of this study will provide useful information to administrators and instructors in the development of distance education courses and programs. Complete anonymity is guaranteed.

The enclosed survey will take approximately 5 minutes of your time. The information will be kept confidential, and the data will be stored securely. There will be no reference made to oral or written reports to link you with this study. If you have any questions concerning this study, please contact Carol L. Fugitt at (606) 615-0444 or carolfugitt@yahoo.com. If you have questions pertaining to your rights as a participant, please contact the Department of Leadership Studies, West Virginia University at (304) 293-5703.

Please answer the questions as honestly and accurately as you can. This questionnaire can be completed online, please save your answers and return to carolfugitt@yahoo.com

Thank you in advance for your participation in this very important research study.

Regards,

Carol L. Fugitt

Doctoral Student

West Virginia University 


\title{
APPENDIX B
}

\author{
GOOD PRACTICES SURVEY MAILED TO \\ DISTANCE EDUCATION FACULTY AT \\ KCTCS
}

\section{Good Practices Survey}

The following questions pertain to your perceptions of the levels of administrative support for distance education at your institution. Please indicate your level of satisfaction with each item below by checking the appropriate box. Please save your answers before you send them back to carolfugitt@yahoo.com

1. At what level of support does your administration provide quality training for faculty involved in distance education?

2. At what level does your institution provide quality support services to faculty involved in distance education?

3. At what level does your institution provide students enrolled in distance education courses access to library resources?

4. At what level does your institution provide students enrolled in distance education courses with academic advising?

5. At what level does the institution provide a commitment to students enrolled in distance education courses to complete a degree or course in a publicized timeframe?

6. At what level does your institution provide faculty access to current technology to improve pedagogy?

7. At what level does your institution provide students enrolled in distance education courses access to current technology?

8. At what level does your institution assess existing distance education programs?

9. At what level does your institution use the results of the assessments to improve the distance education program? 
10. At what level does student-faculty interaction occur in your distance education course?

The following questions pertain to your distance education teaching. Please indicate your perception of the activities below by checking a box for each of the questions.

11. At what level do students interact with other students in your distance education course?

12. At what level do you provide quality feedback to your students?

13. At what level would you rate the quality of student assessment in your distance education course?

14. At what level do you implement current technology to enhance pedagogy?

15. At what level do you provide information for student related to on-line tutoring, library services, self-help materials, counseling, policies and technical support?

16. At what level does student feedback affect modifications you make to on-line course design?

17. At what level does student feedback affect modifications to the goals for your online course(s)?

18. At what level do you utilize student feedback to improve your on-line pedagogy? 